\title{
Update of the Devonian lithostratigraphic subdivision in the subsurface of the Campine Basin (northern Belgium)
}

\author{
DAVid LAGROU ${ }^{*} \&$ MARIE COEN-AUBERT ${ }^{2}$
}

\author{
${ }^{1}$ VITO, Boeretang 200,BE-2400 Mol, Belgium; david.lagrou@vito.be. \\ ${ }^{2}$ DO Terre et Histoire de la Vie (Evolution de la Paléobiosphère), Institut royal des Sciences naturelles de Belgique, rue Vautier \\ 29, B-1000 Bruxelles, Belgium; marie.coen-aubert@naturalsciences.be. \\ "corresponding author
}

\begin{abstract}
The continental and mainly conglomeratic Booischot Formation is formally introduced for the strata intersected close to the base of the Booischot borehole from the Campine Basin. It is nearly $400 \mathrm{~m}$ thick and its upper part is Upper Givetian to Upper Frasnian in age whereas its lower part has not been dated so far. The Booischot borehole is overlain by the Upper Devonian marine Aisemont and Falisolle Formations which are capped by Famennian sandstones assigned to the Evieux Formation. These latter three lithostratigraphic units are also present in the Heibaart borehole, above a few metres of the Middle Frasnian Huccorgne Formation which rest directly on the Caledonian basement of the Brabant Massif, without any trace of the Booischot Formation. It appears that in the Campine Basin, the Devonian transgression arrived very late during the Frasnian. The Devonian succession at the northern margin of the Brabant Massif is very different from that of the north side of the Namur Basin and the Visé area characterized more particularly by the occurrence of Givetian marine deposits. Some rugose corals of this stage are figured for the first time from the Visé area. The conglomerates of the Booischot Formation are also compared to similar thick strata from the Givetian of NW Germany.
\end{abstract}

KEYWORDS: Booischot Formation, Givetian, Frasnian, Famennian, lithostratigraphy, biostratigraphy.

\section{Introduction}

During the systematic lithostratigraphic description of the Palaeozoic deposits from the subsurface of the Campine Basin in northern Belgium (Lagrou, 2012), it appeared that certain stratigraphic intervals in deep boreholes, already identified and investigated as separated units by different authors (Langenaeker, 2000; Laenen, 2003), were not yet formally named. As one of the goals of the detailed stratigraphic study of Lagrou (2012) was to put all data in the Flemish web-based 'Databank Ondergrond Vlaanderen' (DOV), codes for the different lithostratigraphic units were needed. To be in accordance with DOV as well as with the Belgian official stratigraphy, the newly proposed lithostratigraphic units were submitted to the Belgian National Commission on Stratigraphy.

This was the case for the Devonian Booischot Formation which is defined at the base of the Booischot borehole, above the Caledonian basement of the Brabant Massif. The Booischot borehole (Fig. 1A) has been drilled in 1963 for the Geological Survey of Belgium where the collection of cores is still stored and easily available. More generally, we present in this paper a complete stratigraphic overview of the Devonian from the Campine Basin, which has also been intersected by the Heibaart borehole (Fig. 1A). The study of the Heibaart borehole is mainly based on the unpublished report of Cornet (1976) illustrated by two photographic volumes of discontinuous cores with comments, which are stored in the Archives of the Geological Survey of Belgium.

Above or laterally to the Givetian-Frasnian continental deposits of the Booischot Formation, the Upper Devonian marine sediments are represented by the Huccorgne, Aisemont, Falisolle and Evieux Formations which were already partly used by Coen-Aubert (2014).

Detailed lithostratigraphic data about the Givetian and the Frasnian from other areas of Belgium such as the Dinant Synclinorium, the Namur Basin and the Vesdre Massif, provided by Bultynck et al. (1991) and Boulvain et al. (1999), are used in this paper to correlate the deposits of the Campine basin. Following Delmer (2004), the term Namur Basin is used herein with the same meaning as the Campine Basin.

\section{Geological setting}

The Campine Basin belongs to the extensive DevonianCarboniferous basin of NW Europe (Fig. 1A). It is situated at the northern margin of the Brabant Massif, whereas the north side of the Namur Basin lies at its southern border and the Visé area at its eastern end (Fig. 1B). For a European context, we refer to Neumann-Mahlkau \& Ribbert (1998) who composed palaeogeographic and structural maps of the Anglo-Brabant Massif and the Krefeld High in NW Germany, during the Middle Devonian.

The basin evolution in the Campine area started in the Givetian when a transgression flooded the eroded "Old Red Continent". From the Anglo-Brabant Massif, strongly weathered red detritus were transported into the Campine Basin. The oldest dated sediments above the Caledonian basement are Givetian in age in the Booischot borehole towards the south and Frasnian in age in the Heibaart borehole to the north (Legrand, 1964; Bless et al., 1976; Streel \& Loboziak, 1987; Muchez \& Langenaeker, 1993). The Givetian and the continental Frasnian strata, comprising 396 m of mainly red, green and mottled conglomerates and coarse-grained sandstones in the Booischot borehole, are totally absent in the Heibaart borehole. Muchez \& Langenaeker (1993) proposed a sedimentation pattern which may reflect either the influence of a half-graben structure or several grabens (Fig. 2). The comparable thicknesses and facies of the marine Frasnian and Famennian strata in Heibaart (167 m) and Booischot (192 $\mathrm{m})$ suggest that the tilting or block faulting became inactive during that period. In both boreholes, the Famennian is covered by Dinantian carbonates.

\section{Lithological description of the Devonian in the Booischot and Heibaart boreholes}

\subsection{Booischot borehole (Fig. 3)}

Name: GeoDoc 059E0146 (KB132, Booischot), DOV no. kb24d5K9e-B160

Lambert Belgian coordinates: X: 177.651, Y:193.309, Z: 12.6 m

Date: 1963 (started 1/03/1963)

Drilled by Foraky for the Geological Survey of Belgium

Total depth: $1330 \mathrm{~m}$. 


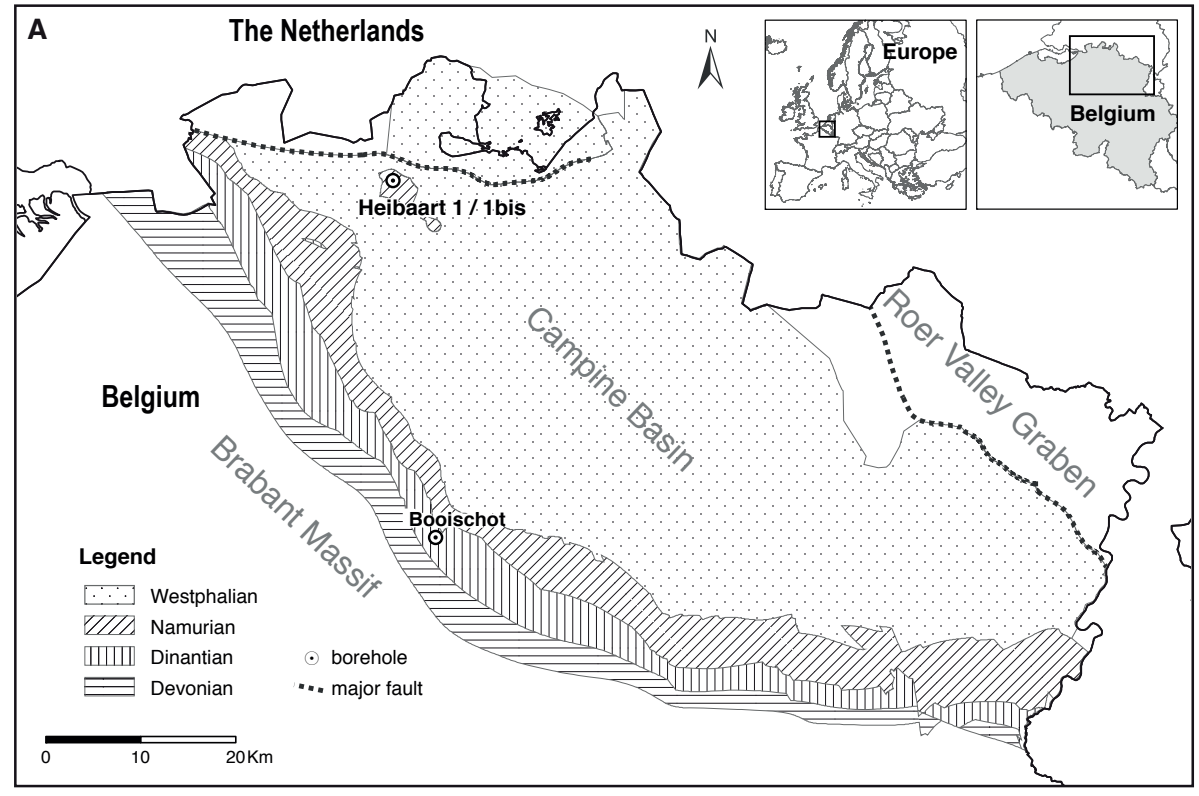

Figure 1. A: Schematic Devonian and Carboniferous subcrop map of the Campine Basin with location of the Booischot and Heibaart boreholes (modified after Langenaeker, 2000). B: Geographical location of most important boreholes and type localities of formations mentioned in the text, with $1=$ Visé $122 \mathrm{~W} 291$ and Visé $122 \mathrm{~W} 292,2=$ Berneau 111 and 3 = Hermalle-sous-Argenteau (Dalhem 122W258).

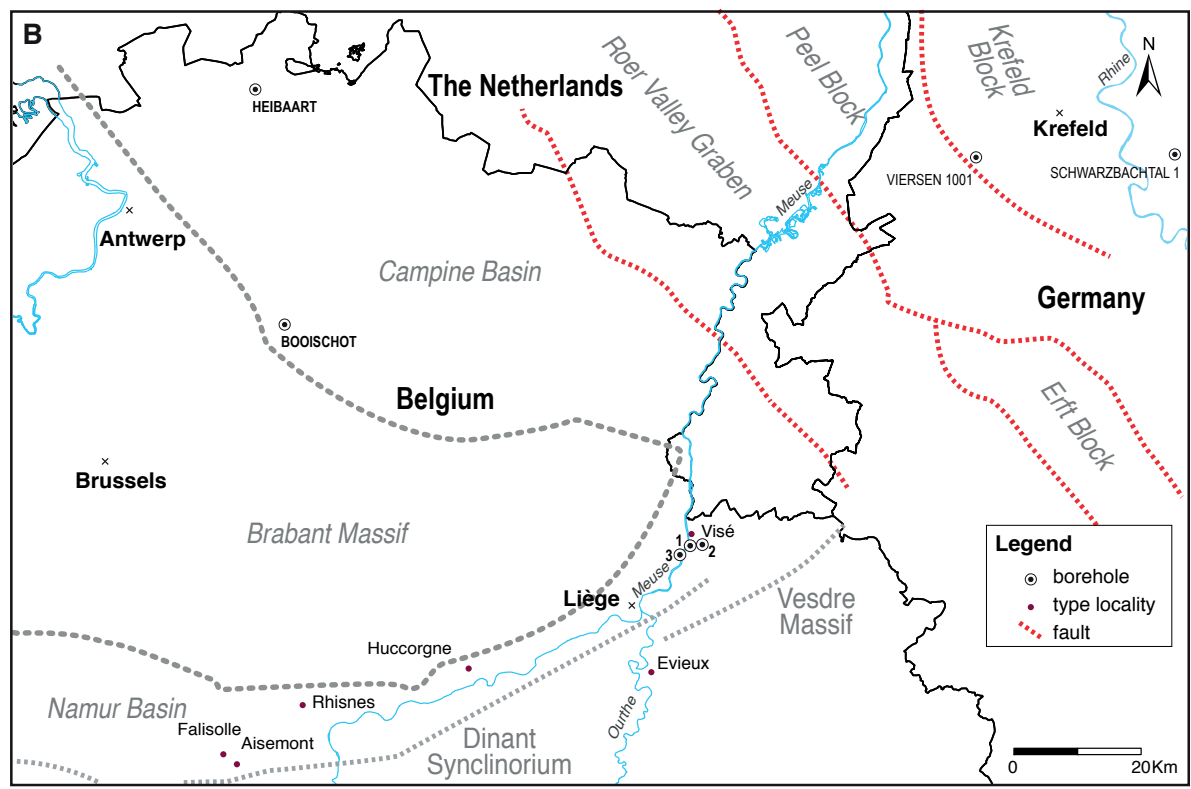

The lithological description is based on Legrand (1964), Bless et al. (1976), Langenaeker (2000) and Coen-Aubert (2014):

- $700 \mathrm{~m}$ to $802 \mathrm{~m}$ : Famennian sandstones represented by green micaceous sandstones (and sedimentary quartzites) with seven conglomeratic levels.

- $802 \mathrm{~m}$ to $892 \mathrm{~m}$ : marine mainly shaly and fossil bearing sequence:

- $802 \mathrm{~m}$ to $839 \mathrm{~m}$ : grey shaly sequence, locally green purple, micaceous or finely laminated;

- 839 m to $841 \mathrm{~m}$ : nodular limestone;

- $841 \mathrm{~m}$ to $867 \mathrm{~m}$ : grey shales (sometimes dark, green or purple); between $849-850 \mathrm{~m}$ : green and micaceous sandstone with plant remains;

- $867 \mathrm{~m}$ to $876 \mathrm{~m}$ : nodular limestone, very argillaceous at the base; occurrence of some brachiopods, crinoids and corals;

- $876 \mathrm{~m}$ to $888 \mathrm{~m}$ : mainly grey, weathered, dolomitized shales;

- $\quad 888 \mathrm{~m}$ to $892 \mathrm{~m}$ : shales with numerous beds of oolitic hematite (Plate 1A); one layer of micaceous sandstone.

- $892 \mathrm{~m}$ to $1288 \mathrm{~m}$ : continental sequence with conglomerates as main lithology:

- $\quad 892 \mathrm{~m}$ to $909 \mathrm{~m}$ : sequence dominated by red argillaceous rocks with two conglomeratic layers, palaeosol and plant remains;

- $909 \mathrm{~m}$ to $930 \mathrm{~m}$ : coarse-grained grey sandstones with conglomerate layers (Plate 1B);
- $\quad 930 \mathrm{~m}$ to $1085 \mathrm{~m}$ : green conglomerates, some grey and green-grey sandstones and coarse-grained quartzites; rarely shales and numerous plant remains;

- $1085 \mathrm{~m}$ to $1275 \mathrm{~m}$ : red conglomerates (Plate 1C); rarely red sandstones and shales;

- $1275 \mathrm{~m}$ to $1288 \mathrm{~m}$ : green and red-green conglomerates, sandstones and shales.

- $1288 \mathrm{~m}$ to $1330 \mathrm{~m}$ : Caledonian basement of the Brabant Massif characterized by black slates to shales with some beds of siltstones and micaceous sandstones (Silurian, Lower Ludlow).

\subsection{Heibaart borehole (Fig. 4)}

Name: GeoDoc 007E0178 (KB129, Loenhout, Heibaart 1/1bis), DOV no. kb8d7e-B216

Lambert Belgian coordinates: X: 173.343, Y: 231.025, Z: $23.4 \mathrm{~m}$

Date: 1962

Drilled by S.C.R.E.M. for Petrofina

Total depth: $1638.65 \mathrm{~m}$.

The lithological description is based on Cornet (1976), Dejonghe (1983), Langenaeker (2000) and Coen-Aubert (2014):

- 1461 to $1533 \mathrm{~m}$ : Famennian sandstones (Plate 2A) represented by fine-grained green, red and mottled sandstones (argillaceous and micaceous) with palaeosols. 


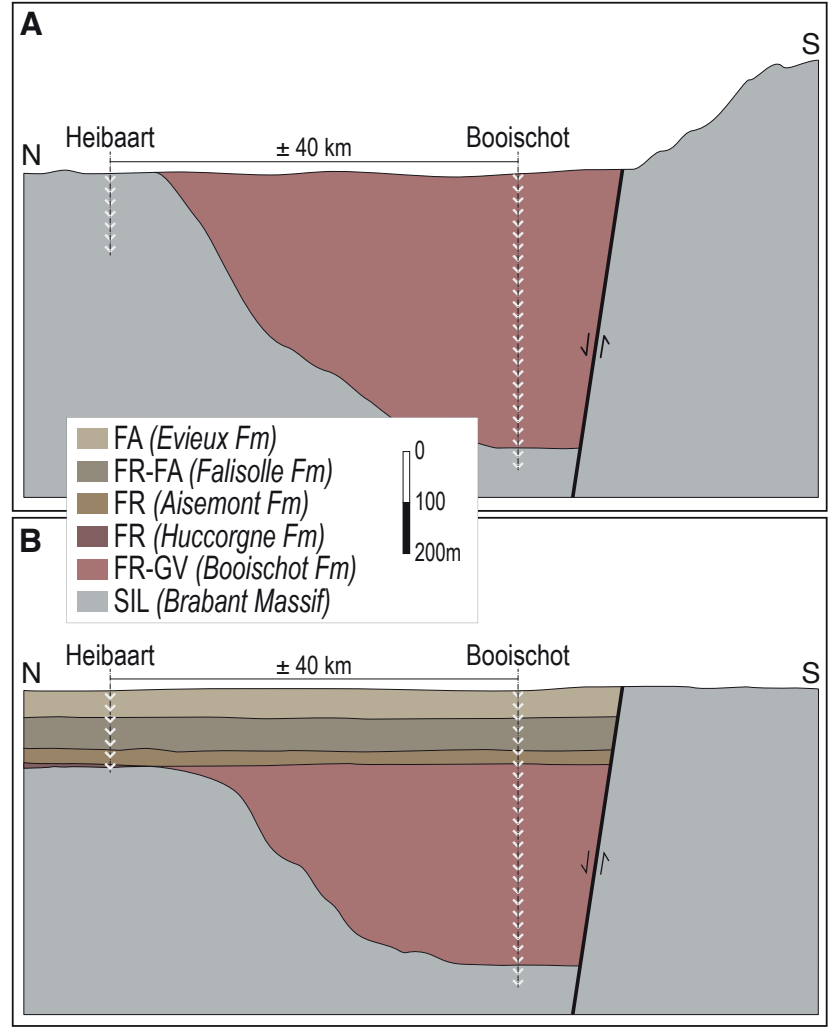

Figure 2. Half-graben model for the Campine Basin at (A) the end of the Frasnian/Givetian continental sequence and (B) at the end of the Famennian (modified after Muchez \& Langenaeker, 1993). Chronostratigraphy: $\mathrm{SIL}=$ Silurian, $\mathrm{GV}=$ Givetian, $\mathrm{FR}=$ Frasnian and FA=Famennian
- 1533 to 1628 m: Lower Famennian and Frasnian marine deposits:

- $1533 \mathrm{~m}$ to $1594.6 \mathrm{~m}$ : silto-micaceous shales (Plate 2B), locally bioclastic with pyrite at the base with few rugose corals;

- $\quad 1594.6$ to $1602 \mathrm{~m}$ : subnodular to nodular limestone with brachiopods, crinoids, gastropods and fragments of corals especially in the upper part: Potyphyllum, solitary rugose corals, Alveolites and ramose tabulate corals (Plate 2C); at the top, mineralization of sulphides in silicified dolomite;

- $1602 \mathrm{~m}$ to $1610 \mathrm{~m}$ : calcareous shales, more or less silty and micaceous (Plate 2D); some remains of brachiopods and crinoids;

- $1610 \mathrm{~m}$ to $1619 \mathrm{~m}$ : argillaceous limestones and calcareous shales;

- 1619 m to $1624.8 \mathrm{~m}$ : calcareous dolomite (Plate 2E), sandy at the base and brecciated at the top; locally abundant bioclasts and pyrite;

- $1624.8 \mathrm{~m}$ to $1628 \mathrm{~m}$ : shales, locally silicified and nodular limestones with coarsely bioclastic levels and fragments of diverse reef building organisms.

- $1628 \mathrm{~m}$ to $1638.65 \mathrm{~m}$ : Caledonian basement of the Brabant Massif characterized by black slates to shales (Plate 2F) with pyrite (Silurian).

\section{Litho- and biostratigraphic interpretation (Table 1)}

Biostratigraphic data concern mainly the Booischot borehole which has been investigated more in detail. Concerning the conodont zonation, it is remembered that the Palmatolepis rhenana and $P$. linguiformis Zones are present in the Upper Frasnian and succeeded by the $P$. triangularis and $P$. crepida Zones in the Lower Famennian (Coen-Aubert, 2016; Denayer et al., 2016).
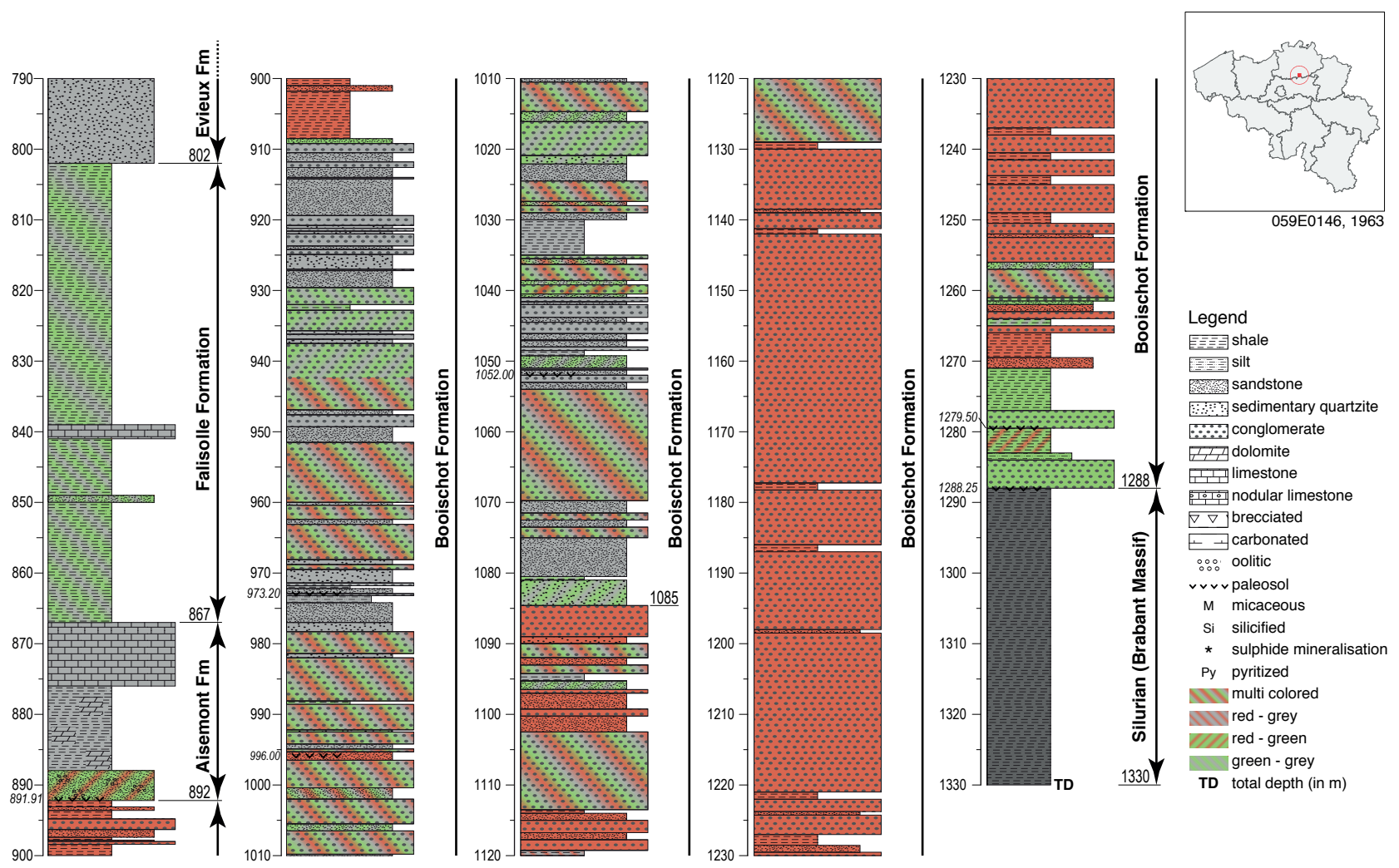

Figure 3. Litholog of the Devonian of borehole 059E146 (KB132, Booischot), stratotype of the Booischot Formation. Lithology based on detailed litholog from Legrand (1964), Bless et al. (1976), Langenaeker (2000) and Coen-Aubert (2014). GeoDoc 059E146. 


\begin{tabular}{|l|l|c|c|c|l|}
\hline \multirow{2}{*}{ Geological age } & \multirow{2}{*}{ Formation } & \multicolumn{2}{|c|}{ Top - bottom in m } & \multirow{2}{*}{$\begin{array}{c}\text { Thickness B/H } \\
\text { (in m) }\end{array}$} & Remarks \\
\cline { 3 - 4 } & & Booischot & Heibaart & $102 / 72$ & Provisional attribution \\
\hline Famennian & Evieux & $700-802$ & $1461-1533$ & $65 / 61.6$ & $\begin{array}{l}\text { (Delcambre \& Pingot, } \\
\text { Famennian/ }\end{array}$ \\
Frasnian & Falisolle & $802-867$ & $1533-1594.6$ & 2000,2014 ) \\
\hline Frasnian & Aisemont & $867-892$ & $1594.6-1624.8$ & $25 / 30.2$ & \\
\hline Frasnian & Huccorgne & $/$ & $1624.8-1628$ & $0 / 3.2$ & \\
\hline $\begin{array}{l}\text { Frasnian/ } \\
\text { Givetian }\end{array}$ & Booischot & $892-1288$ & $/$ & $396 / 0$ & $\begin{array}{l}\text { New continental formation } \\
\text { (Lagrou \& Laenen, 2015) }\end{array}$ \\
\hline Silurian & Ronquières & $1288-1330$ & $1628-1638.65$ & $>42 />10.65$ & $\begin{array}{l}\text { Uncertain attribution of the } \\
\text { formation }\end{array}$ \\
\hline
\end{tabular}

Table 1. Lithostratigraphic subdivision of the Devonian and the underlying Silurian formations in the Booischot (B) and Heibaart (H) boreholes.

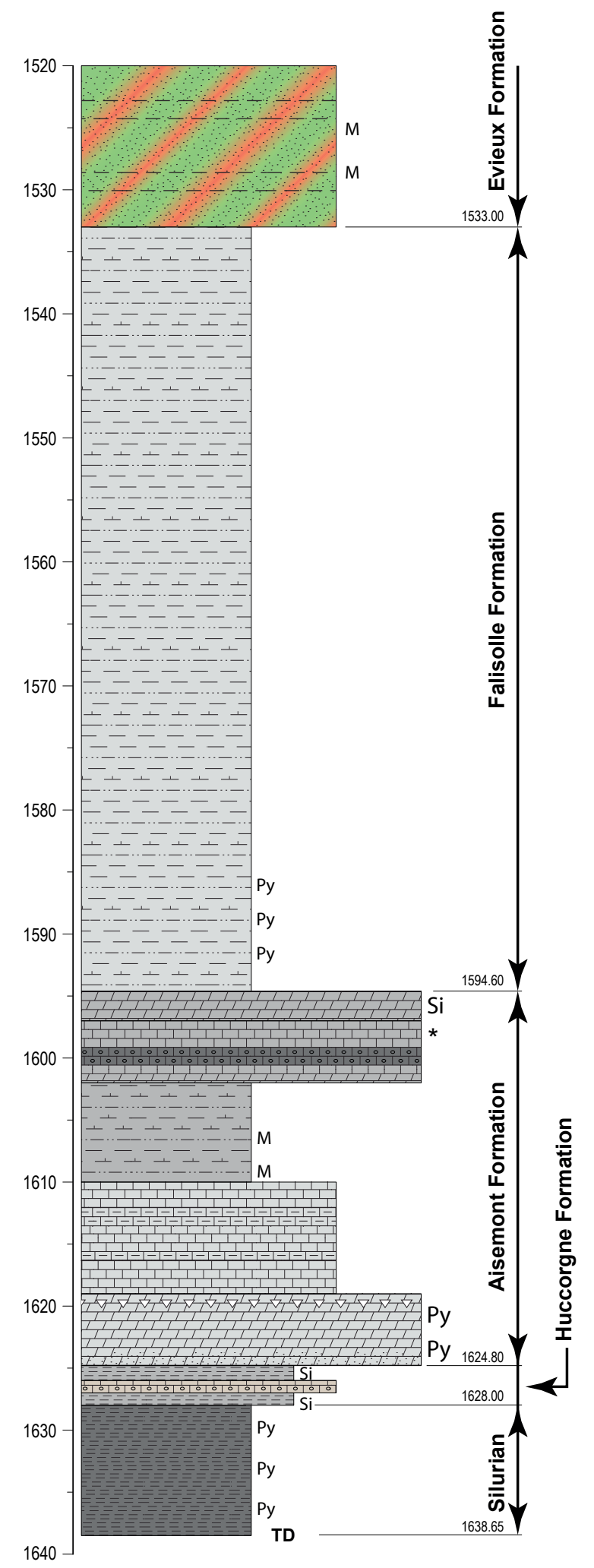

\subsection{Evieux Formation}

The green and red Famennian sandstones with palaeosols are mainly alluvial deposits and are provisionally attributed to the Evieux Formation. These Famennian sandstones are overlain by Dinantian carbonates in both boreholes of Heibaart and Booischot. The Evieux Formation, normally Upper Famennian in age, seems to be the only unit from the Condroz Sandstone Group present in the Campine Basin (Laenen, 2003; Thorez et al., 2006). According to Denayer et al. (2016), a new unnamed formation should be introduced to regroup the classical Montfort and Evieux Formations defined in the Ourthe valley, to the south of Liège.

In the Booischot borehole (Fig. 5), the Pw acritarch Zone has been observed at $755.5 \mathrm{~m}$ (Vanguestaine et al., 1983). It has been recognized by these authors between the Upper Palmatolepis triangularis and the Middle P. crepida conodont Zones, in the Lower Famennian of several localities from the southern part of Belgium. Typical Famennian miospores have been mentioned by Streel (1965) in the same borehole at 775.5 $\mathrm{m}$ and $743 \mathrm{~m}$ without more precisions.

\subsection{Falisolle Formation}

The shaly sequences, which are intersected in the Booischot borehole between $802 \mathrm{~m}$ and $867 \mathrm{~m}$ and in the Heibaart borehole between $1533 \mathrm{~m}$ and $1594.6 \mathrm{~m}$, are laterally equivalent and they are crossing the Frasnian-Famennian boundary. Clearly, they do not belong to the Hodimont Formation characterized by several levels rich in oolitic hematite in its lower part (Laloux et al., 1996) and to the Lambermont Formation (Boulvain et al., 1999) including red and nodular, coralliferous limestones close to its base (Fig. 6); these two lithostratigraphic units are present in the Vesdre Massif. On the contrary, the shaly sequences recognized in the Campine Basin can be assigned to the Falisolle Formation introduced by Delcambre \& Pingot $(2000,2014)$. The stratotype of the Falisolle Formation, situated to the north of the Moreau quarry at Aisemont, on the south side of the Namur Basin, has been described by Delcambre \& Pingot (2014) between the first Famennian sandstones and the Aisemont Formation. The Falisolle Formation (nearly $50 \mathrm{~m}$ thick) consists at Aisemont of green and purple shales with some beds rich in brachiopods and some thin layers of micaceous sandstone in its upper part. In this locality, it is overlain by sandstones which may be assigned successively to the Esneux and the Bois des Mouches Formations, according to Delcambre \& Pingot, (2014). The Bois des Mouches Formation has been introduced by Delcambre \& Pingot (2000) directly above the Falisolle Formation, on the map sheet Fontaine-l'Evêque - Charleroi. The Falisolle, Esneux and Bois des Mouches Formations have been used or discussed recently in the Namur Basin, by Denayer et al. $(2012,2016)$ and Coen-Aubert (2015).

Figure 4. Litholog of the Devonian of borehole 007E0178 (KB129, Heibaart). Lithology based on detailed litholog from Cornet (1976), Dejonghe (1983), Langenaeker (2000) and Coen-Aubert (2014). GeoDoc 007E178. (For legend see Fig. 3). 


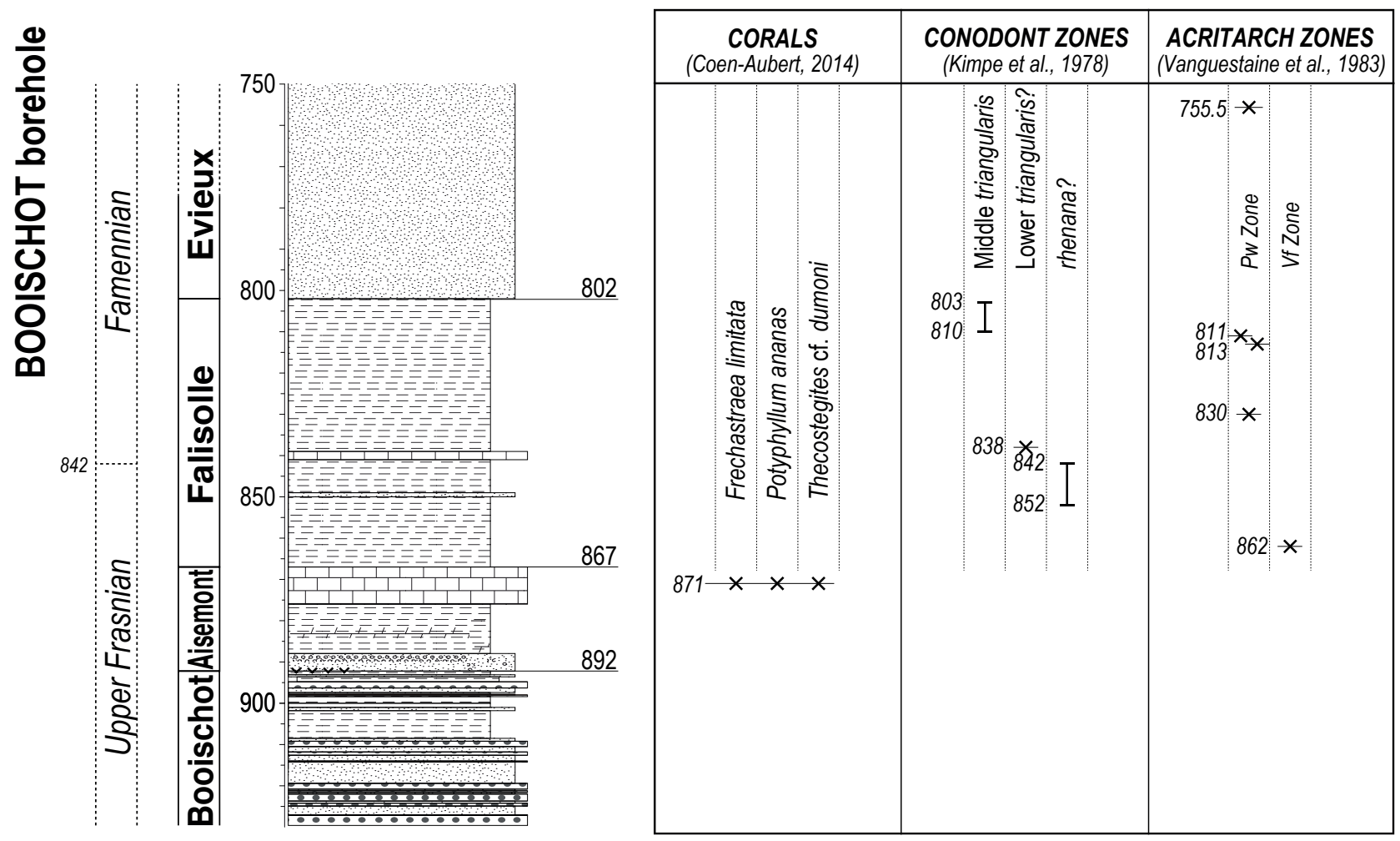

Figure 5. Biostratigraphic data for rugose and tabulate corals, conodont and acritarch Zones in the Upper Frasnian marine deposits of the Booischot borehole. (For legend see Fig. 3).

In the Heibaart borehole, one colony of the rugose coral Frechastraea pentagona has been identified by Coen-Aubert (2014), at the base of the Falisolle Formation. This species is also present in the Lambermont Formation. Several micropalaeontological data are available for the Booischot borehole (Fig. 5). Concerning the conodonts, Kimpe et al. (1978) have recognized the Middle Palmatolepis triangularis Zone between $803 \mathrm{~m}$ and $810 \mathrm{~m}$, probably the Lower $P$. triangularis Zone at $838 \mathrm{~m}$ and also probably the $P$. rhenana Zone between $842 \mathrm{~m}$ and $852 \mathrm{~m}$ with among others Ancyrodella curvata. This species and more generally the genus Ancyrodella are restricted to the Frasnian stage in Belgium (Gouwy \& Bultynck, 2000), Germany (Ziegler \& Sandberg, 1990) and France where the Frasnian-Famennian Global Stratotype Section and Point (GSSP) have been fixed near the Upper Coumiac Quarry (Montagne Noire) and studied among others by Klapper et al. (1993). In the Booischot borehole, the $\mathrm{Pw}$ acritarch Zone is still present at $811 \mathrm{~m}, 813 \mathrm{~m}$ and $830 \mathrm{~m}$ according to Vanguestaine et al. (1983). These authors have also identified the Vf Zone at $862 \mathrm{~m}$ which is characteristic of the Upper Frasnian and the Upper Palmatolepis rhenana conodont Zone. Clearly, the $\mathrm{Bb}, \mathrm{Bm}$ and $\mathrm{Vg}$ acritarch Zones are lacking in the Booischot borehole between the $\mathrm{Pw}$ and Vf Zones and there are some contradictions between the conodont and acritarch data, close to the Frasnian-Famennian boundary which has been provisionally placed at $842 \mathrm{~m}$.

\subsection{Aisemont Formation}

The sequence below the Falisolle Formation can be attributed to the Aisemont Formation. In the type area, the formation is subdivided into three members. The upper level consists of dolostones or limestones with algae, massive colonial rugose corals, stromatoporoids, tabulate corals and bryozoans. The middle level is mainly made up of shales. The lower level is composed of bedded argillaceous limestones with massive colonial rugose corals (Bultynck \& Dejonghe, 2002). In the Booischot borehole (Fig. 3), the nodular limestones between $867 \mathrm{~m}$ and $876 \mathrm{~m}$ can be assigned to the upper part of the Aisemont Formation. The shales below ( $876 \mathrm{~m}$ to $888 \mathrm{~m}$ ) may be referred to the middle part of the Aisemont Formation. The oolitic hematite facies $(888 \mathrm{~m}$ to $892 \mathrm{~m})$ recalls the Presles Formation from the base of the Frasnian (Fig. 6).
But miospores from the underlying Booischot Formation show that the ferruginous shales are certainly younger than the Presles Formation. Coen-Aubert (2014) interpreted this oolitic layer as a typical deposit occurring at the transition of a regressive to a transgressive phase (Laenen et al., 2002). In the lithostratigraphic subdivision proposed herein, this unit is included at the base of the Aisemont Formation.

Such oolitic ironstones appear at an abrupt transition between a regression and a transgression; there are several of them at the base of the Hodimont Formation. On the south side of the Dinant Synclinorium, beds with ferruginous oolites are locally present at the base of the mostly shaly Nismes Formation (Coen, 1974; Boulvain et al., 1999). No particular lithostratigraphic name has been proposed for these local facies with ferruginous oolites. According to our interpretation, beds with oolitic hematite occur rather low in the Upper Frasnian Aisemont Formation intersected by the Booischot borehole. They are not present in the Heibaart borehole.

In the Heibaart borehole (Fig. 4), the subnodular limestone unit (1594.6 $\mathrm{m}$ to $1602 \mathrm{~m}$ ) below the Falisolle Formation is attributed to the upper part of the Aisemont Formation; it contains tabulate and rugose corals with among them massive colonies of Potyphyllum (probably P. ananas). The underlying calcareous shale unit $(1602 \mathrm{~m}$ to $1610 \mathrm{~m})$ corresponds to the middle part of the Aisemont Formation. The unit between $1610 \mathrm{~m}$ and $1624.8 \mathrm{~m}$ consists of calcareous dolomite, argillaceous limestones and calcareous shales and can be assigned to the lower level of the Aisemont Formation (Coen-Aubert, 2014). This means that the three units of the Aisemont Formation are present in the Heibaart borehole.

In the Booischot borehole, the tabulate coral Thecostegites cf. dumoni as well as the massive rugose corals Frechastraea limitata and Potyphyllum ananas have been identified by Coen-Aubert $(2014,2016)$ at $871 \mathrm{~m}$. The latter two species are highly characteristic of the upper limestone level from the Aisemont Formation whereas Thecostegites dumoni is a rare taxon occurring in the Les Valisettes Member from the Champ Broquet Formation in the Philippeville Massif (CoenAubert, 2014). 


\begin{tabular}{|c|c|c|c|c|c|c|}
\hline & NORTH SIDE OF THE & \multirow{2}{*}{ VESDRE MASSIF } & \multicolumn{4}{|c|}{ NORTH SIDE OF THE NAMUR BASIN } \\
\hline & $\begin{array}{l}\text { AND SOUTH SIDE OF } \\
\text { THE NAMUR BASIN }\end{array}$ & & \multicolumn{2}{|r|}{ CENTRAL PART } & \multicolumn{2}{|c|}{ EASTERN PART } \\
\hline $\mathbb{1}$ & \multirow{2}{*}{$\begin{array}{l}\text { FALISOLLE } \\
\text { FORMATION }\end{array}$} & HODIMONT FORMATION & \multirow{3}{*}{\multicolumn{2}{|c|}{$\begin{array}{l}\text { G A P AND } \\
\text { FALISOLLE } \\
\text { FORMATION }\end{array}$}} & \multirow{2}{*}{\multicolumn{2}{|c|}{ G A P }} \\
\hline \multirow{3}{*}{$\begin{array}{l}z \\
< \\
- \\
z\end{array}$} & & $\begin{array}{l}\text { LAMBERMONT } \\
\text { FORMATION }\end{array}$ & & & & \\
\hline & AISEMONT FORMATION & AISEMONT FORMATION & & & AISE & MONT FORMATION \\
\hline & \multirow{3}{*}{ LUSTIN } & \multirow{3}{*}{ LUSTIN } & \multirow{3}{*}{ 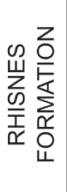 } & Falnuée Member & \multirow{3}{*}{ 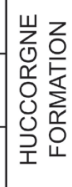 } & Mehaigne Member \\
\hline$\infty$ & & & & Golzinne Member & & Robiewez Member \\
\hline \multirow{3}{*}{$\begin{array}{l}\varangle \\
\simeq \\
\longleftarrow\end{array}$} & & & & Watiamont Member & & Biénonsart Member \\
\hline & FORMATION & FORMATION & \multirow{2}{*}{\multicolumn{2}{|c|}{$\begin{array}{l}\text { BOVESSE } \\
\text { FORMATION }\end{array}$}} & \multicolumn{2}{|r|}{ BOVESSE } \\
\hline & $\begin{array}{l}\text { NISMES OR PRESLES } \\
\text { FORMATION }\end{array}$ & $\begin{array}{l}\text { NISMES OR PRESLES } \\
\text { FORMATION }\end{array}$ & & & & FORMATION \\
\hline
\end{tabular}

Figure 6. Lithostratigraphy of the Frasnian from the north side of the Dinant Synclinorium, the Namur Basin and the Vesdre Massif. FA = Famennian.

\subsection{Huccorgne Formation}

Above the Caledonian basement of the Heibaart borehole, Coen-Aubert (2014) mentioned $3.2 \mathrm{~m}$ of shales and nodular limestones (1624.8 $\mathrm{m}$ to $1628 \mathrm{~m}$ ) containing a fauna which is certainly different from that of the Aisemont Formation. Indeed, it is characterized by the occurrence of unidentified species of Amphipora, Stachyodes, Scoliopora, a fragment of Thecostegites bouchardi and a very small remain of a massive cerioid rugose coral. This facies recalls the Rhisnes and Huccorgne Formations (Fig. 6) which are laterally equivalent on the north side of the Namur Basin and which have been described by Boulvain et al. (1999). Such reef-building organisms are present in the Mehaigne Member, at the upper part of the Huccorgne Formation, but they are not typical of the nodular limestones at the top of the Rhisnes Formation. However, it is difficult to assign only a few metres of sediments to a particular lithostratigraphic unit.

\subsection{Booischot Formation}

In the Booischot borehole, a nearly $400 \mathrm{~m}$ thick sequence of mainly red conglomerates is found between the base of the Aisemont Formation ( $892 \mathrm{~m}$ ) and the top of the Caledonian basement (1288 m) (Fig. 3). This unit, informally known as the Booischot Formation for a long time, has recently been accepted as a formal lithostratigraphic unit (Lagrou \& Laenen, 2015). The Booischot Formation is composed of red, green and mottled conglomerates interbedded with green and grey sandstones and shales. Locally palaeosols are present. In the Booischot borehole, the $396 \mathrm{~m}$ thick sequence can be subdivided into two units: an upper unit $(892 \mathrm{~m}$ to $1085 \mathrm{~m}$ ) of mostly green to grey conglomerates, sandstones and quartzites with a few thin shale beds in which several palaeosols are developed, and a lower unit (1085 m to $1288 \mathrm{~m}$ ) dominated by red conglomerates with occasional palaeosols. In the Campine Basin, the thickness and the presence of the Booischot Formation are highly variable as evidenced by its absence in the Heibaart borehole. This could be due to the deposition in a half-graben system, along the northern margin of the Brabant Massif (Muchez \& Langenaeker, 1993).

In the lower red unit of the Booischot Formation (Fig. 7), plant remains are very rare and only represented between $1258 \mathrm{~m}$ and $1085 \mathrm{~m}$ by sporangia assigned to Svalbardia or Archaeopteris according to Streel (1965) and Streel \& Loboziak (1987). The same authors mentioned the occurrence of Archaeopteris fimbriata (probably synonymous with $A$. macilenta) at different levels between $1089.6 \mathrm{~m}$ and $908.5 \mathrm{~m}$. This plant is characteristic of the Upper Devonian. Additionally, the stratigraphic distribution of different taxa of miospores has been provided by Streel \& Loboziak (1987) between $1120 \mathrm{~m}$ and $900.5 \mathrm{~m}$. The zones TA, TCo and possibly BJ have been recognized respectively at $1120 \mathrm{~m}, 1078$ $\mathrm{m}$ and $1023 \mathrm{~m}$. The age of this interval is Givetian to Middle Frasnian. However, the occurrence of Ancyrospora ancyrea ancyrea at $1078 \mathrm{~m}$ and $1037 \mathrm{~m}$ suggests an age close to the Givetian-Frasnian boundary without more precision. The zone BM present between $1002 \mathrm{~m}$ and $994.5 \mathrm{~m}$ corresponds in the Boulonnais (northern France) to the Middle-Upper Frasnian conodont zones between the Middle Polygnathus asymmetricus and Ancyrognathus triangularis Zones (Boulvain et al., 1999). As explained by Coen-Aubert (2014), the miospores zones IVA, C and E identified by Streel \& Loboziak (1987) between $940 \mathrm{~m}$ and $900.5 \mathrm{~m}$ have been compared with those of the Hydrequent Formation from the Boulonnais so that their age is clearly Upper Frasnian.

In conclusion, the age of the upper part of the Booischot Formation based on plants and miospores is Upper Givetian to Upper Frasnian between $1120 \mathrm{~m}$ and $900.5 \mathrm{~m}$. On the contrary, no precise identifications of fossils are available below $1120 \mathrm{~m}$ so that there is no evidence about the age of the lower part of the Booischot Formation.

\section{Comparison with other areas around the Brabant Massif}

\subsection{North side of the Namur Basin}

For the Frasnian marine deposits of the Booischot and Heibaart boreholes (Fig. 8), the correlations proposed by Coen-Aubert (2014) are confirmed by the new observations presented herein. The Huccorgne Formation is reduced to a few metres above the Silurian basement of the Brabant Massif, in the Heibaart borehole. This lithostratigraphic unit is known at Huccorgne and Lavoir (Coen-Aubert \& Lacroix, 1985), in the eastern part of the north side of the Namur Basin where it is capped by the Aisemont Formation (Fig. 6). This is also the case in the Heibaart borehole. In the Booischot borehole where the Huccorgne Formation is missing, the Frasnian transgression started later, during the Aisemont Formation. In both boreholes, the overlying Falisolle Formation which crosses the Frasnian-Famennian boundary is recognized for the first time to the north of the Brabant Massif. Famennian micaceous sandstones have been intersected at the top of the Devonian, in both drillholes.

The situation is very different for the terrigenous and mostly conglomeratic Booischot Formation which reaches a thickness of about $400 \mathrm{~m}$ in the Booischot borehole. Other 


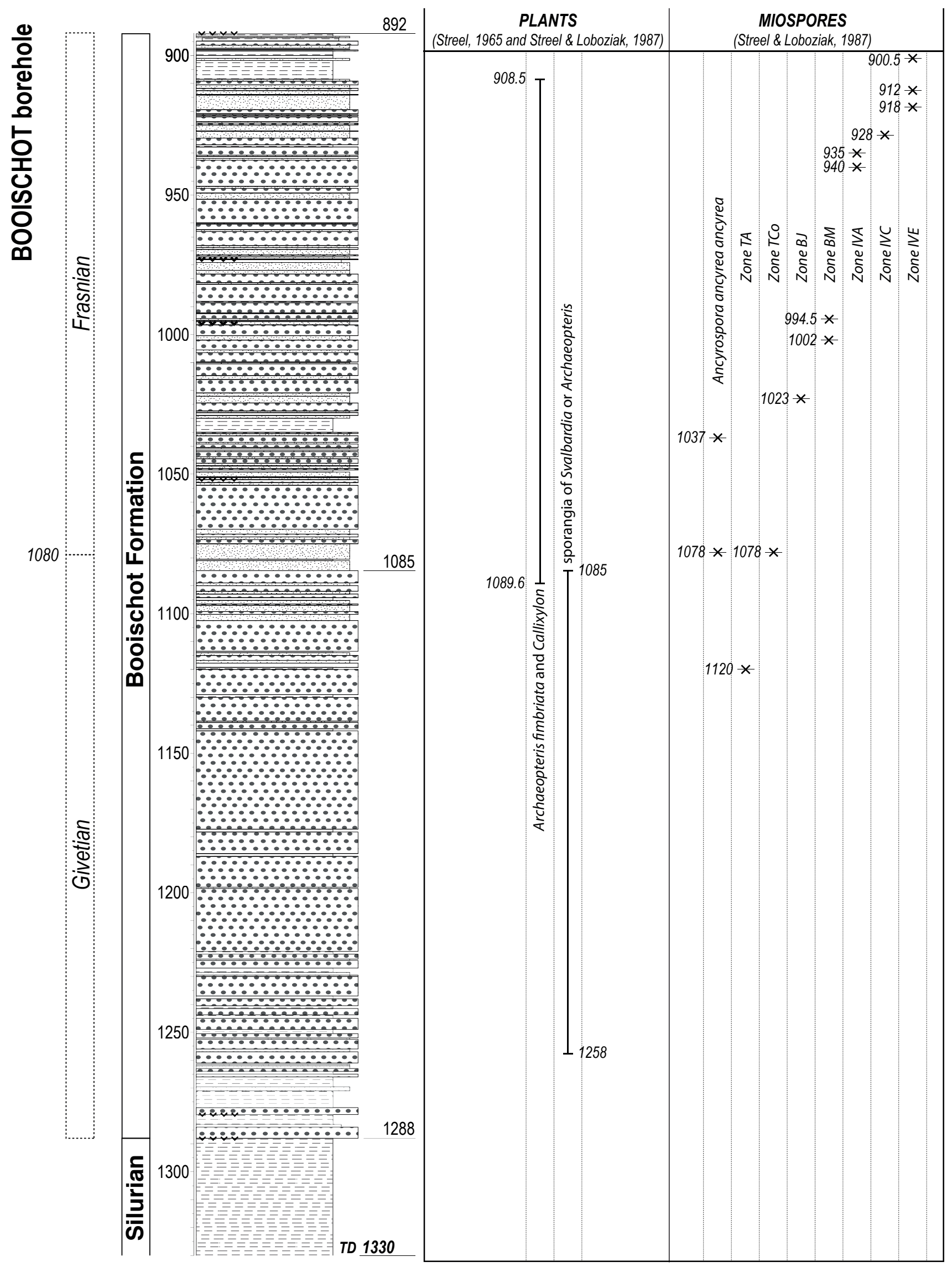

Figure 7. Biostratigraphic data for plant remains and miospores identified in the Booischot Formation from the Booischot borehole. (For legend, see Fig. 3). 


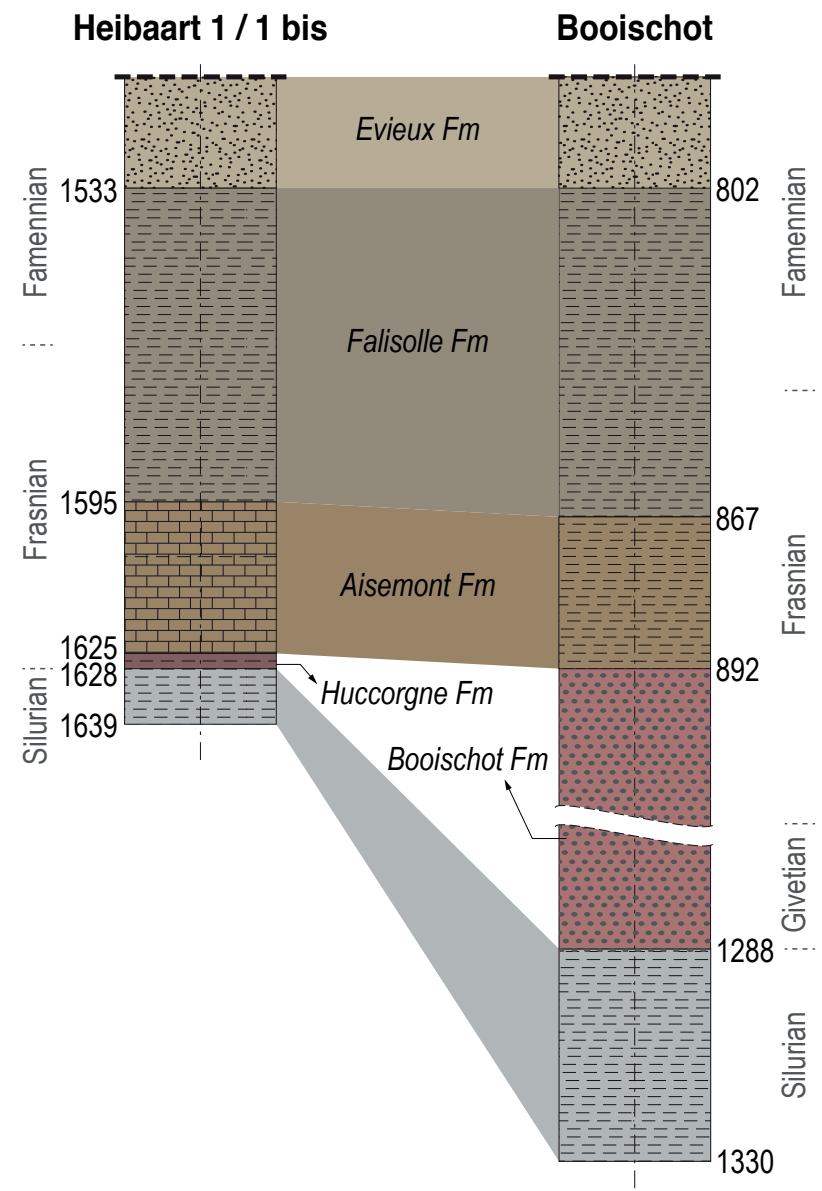

Figure 8. Lithostratigraphic correlations between the Booischot and Heibaart boreholes. (For legend, see Fig. 3).

partly continental strata have been observed above the Caledonian basement of the Brabant Massif, in different localities on the north side of the Namur Basin (Bultynck et al., 1991). These are represented by some Givetian levels and beds with pebbles, gravels or red sediments occurring in the Bois de Bordeaux Formation (Fig. 9), at the base of the Mautiennes Member and locally in the Mazy Member (Bultynck et al., 1991). The overlying Frasnian deposits of this structural unit are represented by the Bovesse Formation and the Rhisnes Formation which passes laterally into the Huccorgne Formation (Fig. 6). These three lithostratigraphic units are marine equivalents of the upper part of the Booischot Formation that is Frasnian in age.

\subsection{Visé area}

The Visé area is situated at the eastern end of the axial part of the Brabant Massif where the Silurian basement consists of rhyolites and rhyolitic tuffs (Duchesne et al., 2005). This area is a complex palaeogeographic unit (Poty \& Delculée, 2011). There are few outcrops of Devonian, but the system is mostly known in four boreholes investigated by Graulich et al. (1975) and Poty (1982, 1991, fig. 3 with a map of location): Hermalle-sous-Argenteau (Dalhem 122W258), Berneau 111 and Visé 122W291 and 292 (Fig. 1B). Kimpe et al. (1978) and Barchy \& Marion (2000) provided also interesting comments about these boreholes.

In the Visé boreholes, the Devonian starts with conglomerates doubtfully referred to the Givetian and quickly succeeded by a thick cyclopean breccia assigned to the Middle Frasnian Lustin Formation by Poty $(1982,1991)$. This facies has also been intersected by the Berneau 111 borehole and by the Hermalle-sous-Argenteau borehole where it is separated from the Silurian basement between $338.30 \mathrm{~m}$ and $300 \mathrm{~m}$, by a bedded succession described in detail by Graulich et al. (1975).

At the base of the Devonian from the Hermalle-sousArgenteau borehole, there are conglomerates with pebbles of rhyolitic tuffs followed by sandy limestones and more or less calcareous shales with massive stromatoporoids, ramose tabulate corals and massive colonies of Columnaria intermedia Coen-Aubert, 1990 at $331 \mathrm{~m}$ (Fig. 10). After about $10 \mathrm{~m}$ of more or less calcareous shales, limestones were intersected; they first contain brachiopods, crinoids and fragments of Temnophyllum wellinense Coen-Aubert, 2003 at $318 \mathrm{~m}$ and 317 $\mathrm{m}$ and finally diverse stromatoporoids and again fragments of Temnophyllum. As shown by Coen-Aubert (2003, 2008), T. wellinense is a species characteristic of the base of the Terre d'Haurs Formation, on the south side of the Dinant Synclinorium (Fig. 9). In the same structural unit, Columnaria intermedia has been introduced by Coen-Aubert (1990), at the base of the underlying Trois-Fontaines Formation; but this taxon is also present at the top of the Trois-Fontaines Formation and at the base of the Terres d'Haurs Formation in the quarries of Marenne and Hampteau located and described by Barchy et al. (2004) and Coen-Aubert (2008), in the vicinity of Hotton, on the southeast side of the Dinant Synclinorium. The name Hexagonaria rohrensis has been used by Graulich et al. (1975) for the material of Hermalle-sousArgenteau as it resembles the figured specimen assigned to this species by Sorauf (1967, fig. 11, 3). However, this colony from the base of the Trois-Fontaines Formation belongs clearly to Columnaria intermedia though its septa do not reach systematically the centre of the corallites. The conodont Polygnathus xylus mentioned by Graulich et al. (1975) at 314 $\mathrm{m}$, in the Hermalle-sous-Argenteau borehole, has also been identified by Gouwy \& Bultynck (2003) at the base of the Bois de Bordeaux Formation, on the north side of the Namur Basin. According to Bultynck (1987), P. xylus appears at the base of the $P$. timorensis Zone that is to say within the Terres d'Haurs Formation (Fig. 9). Thus the conodont data confirm the age based on rugose corals for the Givetian limestones of Hermalle-sous-Argenteau. From a lithostratigraphic point of view, this alternation of shales and limestones can probably be assigned to the Alvaux Member of the Bois de Bordeaux Formation and preferably to its lower part.

\begin{tabular}{|c|c|c|}
\hline $\begin{array}{l}\text { SOUTH SIDE OF THE } \\
\text { DINANT } \\
\text { SYNCLINORIUM }\end{array}$ & \multicolumn{2}{|r|}{$\begin{array}{l}\text { NORTH SIDE } \\
\text { OF THE } \\
\text { NAMUR BASIN }\end{array}$} \\
\hline $\begin{array}{l}\text { FROMELENNES } \\
\text { FORMATION }\end{array}$ & \multirow{3}{*}{ 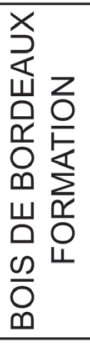 } & Mazy Member \\
\hline $\begin{array}{l}\text { MONT D'HAURS } \\
\text { FORMATION }\end{array}$ & & Alvaux Member \\
\hline $\begin{array}{c}\text { TERRES D'HAURS } \\
\text { FORMATION }\end{array}$ & & Mautiennes Member \\
\hline $\begin{array}{l}\text { TROIS-FONTAINES } \\
\text { FORMATION }\end{array}$ & \multirow{2}{*}{\multicolumn{2}{|c|}{$\begin{array}{c}\text { CALEDONIAN BASEMENT } \\
\text { OF THE } \\
\text { BRABANT MASSIF }\end{array}$}} \\
\hline $\begin{array}{l}\text { HANONET } \\
\text { FORMATION }\end{array}$ & & \\
\hline
\end{tabular}

Figure 9. Lithostratigraphy of the Givetian from the south side of the Dinant Synclinorium and the north side of the Namur Basin. The correlations between the two areas are mainly based on the stratotype of the Bois de Bordeaux Formation at Alvaux and Mazy described by Bultynck et al. (1991). 
In the Visé boreholes, a few metres of shales have been observed between the top of the Middle Frasnian cyclopean breccia and the first partly brecciated limestones of the Lower Visean. In the same context, such mainly black shales and argillaceous limestones have been better investigated in the Berneau 111 borehole and at the base of La Folie quarry at Visé. Their age is Upper Frasnian on the basis of conodonts, acritarchs and foraminifers mentioned by Kimpe et al. (1978) and Poty (1982). These argillaceous limestones contain also colonies of Frechastraea minima and Phillipsastrea falsa, which are only known elsewhere in Belgium, in the Upper Frasnian of the Philippeville Massif (Coen-Aubert, 2016). So the Devonian of the Vise area is very different from that of the Campine Basin.

\subsection{NW Germany}

Some German authors such as Neumann-Mahlkau \& Ribbert (1998) have compared the sediments of the Booischot Formation with Givetian conglomerates mostly known by two boreholes drilled in NW Germany (North Rhine-Westphalia) and investigated in great details. In the Viersen borehole 1001 situated $15 \mathrm{~km}$ to the SW of Krefeld, in the Krefeld High (Fig. 1B), coarse, fossiliferous, phyllitic conglomerates composed of epimetamorphic schists have been intersected between $1463.4 \mathrm{~m}$ and $1573 \mathrm{~m}$, with a thickness of about 110 $\mathrm{m}$. Givetian rugose and tabulate corals such as Grypophyllum cf. postprimum and Caliapora battersbyi have been identified by Birenheide (1998) at $1464.6 \mathrm{~m}$ and $1484.5 \mathrm{~m}$, in their uppermost part where other shallow water fossils such as stromatoporoids and brachiopods are also present. According to Neumann-Mahlkau \& Ribbert (1998), the conglomerates of the Viersen 1001 borehole were formed in a marine, nearshore and high energy environment.
The Schwarzbachtal conglomerates have been observed among others in the borehole Schwarzbachtal 1 (Fig. 1B) drilled near Ratingen to the NE of Düsseldorf, in the Velbert Anticline. They have been intersected in this borehole between $1.7 \mathrm{~m}$ and $44.5 \mathrm{~m}$ (Hauptkonglomerat), but beds of conglomerates are still present between $44.5 \mathrm{~m}$ and 99.5 $\mathrm{m}$, with sandstones and locally carbonate content as well as marine fossil remains (Mergelsberger Schichten). According to Ribbert (1982), only the lower $100 \mathrm{~m}$ of the Schwarzbachtal conglomerates have been drilled in the borehole; their total thickness is about $300 \mathrm{~m}$ as known by the different outcrops figured by Ribbert (1982, fig. 1). And the entire conglomeratic sequence has been assigned to the Middle Givetian by Ribbert (1998). It is interpreted as a prograding fan-delta with a transition from a marine to a terrestrial environment.

The top of the conglomerates in the two areas of Viersen 1001 and Schwarzbachtal 1 does certainly not reach the base of the Frasnian. There are also some sedimentological differences with the Booischot Formation, especially for the borehole Viersen 1001. Therefore, it is difficult to compare the Booischot Formation with these two German Givetian conglomerates. In any case, the Frasnian age of the upper part of the Booischot Formation was already mentioned by Streel \& Paproth (1982) in a paper devoted to the Schwarzbachtal 1 borehole. Another difference with the Booischot borehole observed by these two authors concerns the occurrence of an Upper Eifelian to Lower Givetian spore assemblage in continental shales lying below the basal marine Schwarzbachtal conglomerates. All the Givetian to Eifelian succession below the Schwarzbachtal conglomerates has been figured by Ribbert (1998) whereas in the Campine Basin, the conglomerates of the Booischot Formation rest directly on the Caledonian basement of the Brabant Massif.
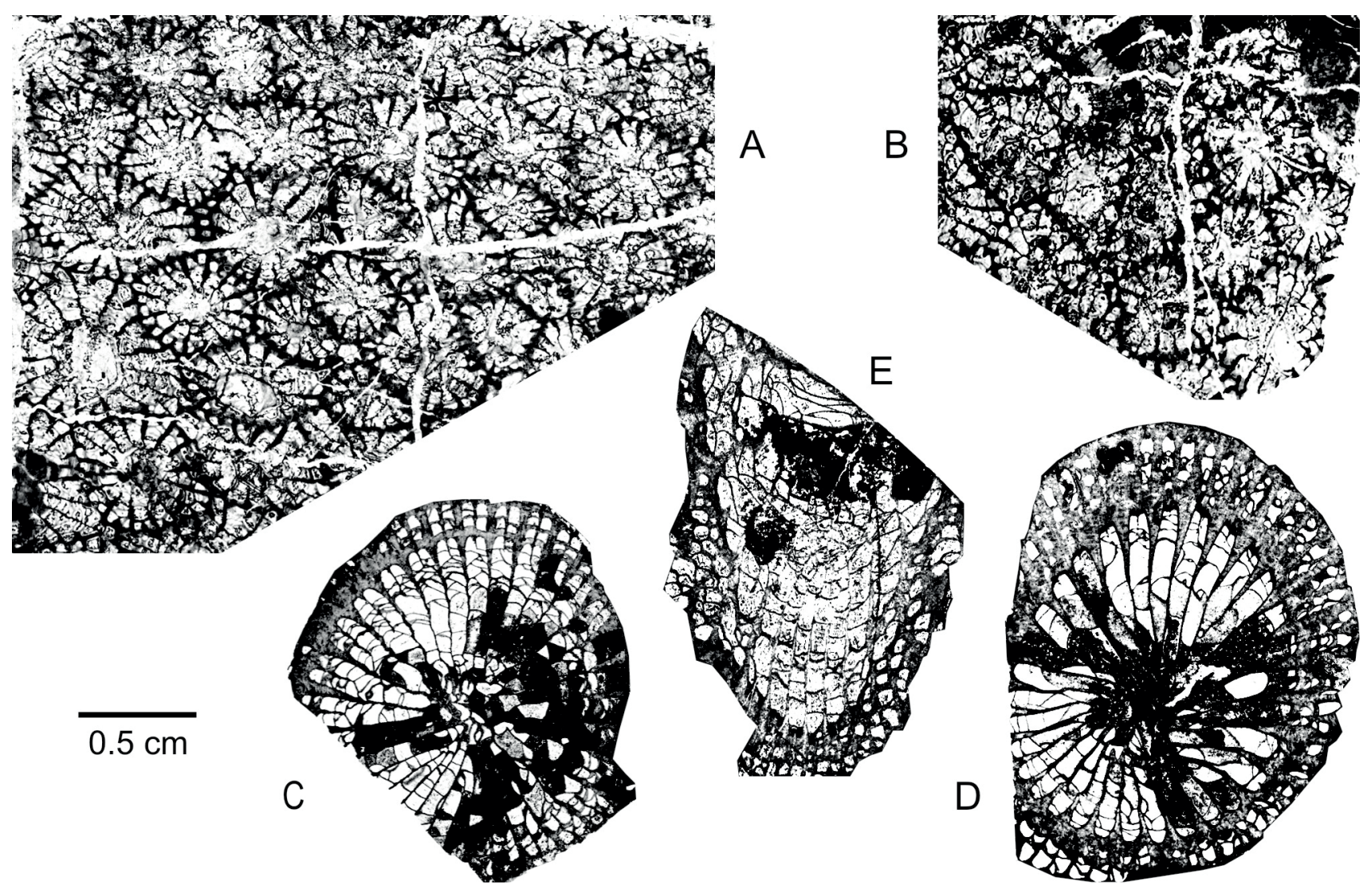

Figure 10. Givetian rugose corals from the borehole Dalhem $122 \mathrm{~W} 258$ at Hermalle-sous-Argenteau. The figured specimens are stored in the Collection of Palaeontology from the Institut royal des Sciences naturelles de Belgique (IRScNB). A-B: Columnaria intermedia Coen-Aubert, 1990. IRScNB a13051 at $331 \mathrm{~m}$; transverse sections. C-E: Temnophyllum wellinense Coen-Aubert, 2003. C: IRScNB a13052 at 317 m; transverse section. D: IRScNB a13053 at 318 m; transverse section. E: IRScNB a13054 at $311 \mathrm{~m}$, longitudinal section. Magnification x 3. 


\section{Conclusion}

The very thick and typically conglomeratic Booischot Formation is highly particular. This continental and probably relatively localized deposit is at present time only known in the Booischot borehole. It has been interpreted as a non-marine valley fill by Kimpe et al. (1978) and as the infilling of a graben structure by Muchez \& Langenaeker (1993), during Givetian and Frasnian. The Devonian transgression arrived very late in the Campine Basin: at the top of the Middle Frasnian in the Heibaart borehole and during the Upper Frasnian in the Booischot borehole which was situated closer to the shoreline, along the northern margin of the Brabant Massif.

On the north side of the Namur Basin and in the Visé area, the Devonian transgression started earlier during Givetian times. In fact, these two regions occupied a more southern position than the Booischot and Heibaart boreholes, respectively at the southern margin and eastern end of the Brabant Massif. So the Givetian-Famennian succession is more complete on the north side of the Namur Basin and the Visé area than in the Campine Basin. However, this succession is affected by several stratigraphic gaps (Fig. 6), especially in the Visé area which was very unstable at that time as already mentioned by Poty (1991) and Coen-Aubert (2014).

\section{Acknowledgements}

The authors thank the Land and Soil Protection, Subsoil, and Natural Resources Division (ALBON) of the Flemish Government for agreement to publish these stratigraphical results of the subsurface mapping of Flanders. Katleen Van Baelen (VITO) is thanked for her excellent work on the figures and Marleen De Ceukelaire and Michiel Dusar from the Geological Survey of Belgium for providing photos of both boreholes. The authors are also grateful to Noël Vandenberghe, President of the National Commission on Stratigraphy and to Markus Aretz, Bernard Mottequin and Annick Anceau who reviewed very carefully the manuscript.

\section{References}

Barchy, L., Coen-Aubert, M., Marion, J.M. \& Coen, M., 2004. Mise en évidence de la Faille de Marenne sur la carte géologique Aye - Marche-en-Famenne. Bulletin de l'Institut royal des Sciences naturelles de Belgique, Sciences de la Terre, Supplément, 74, 59-71.

Barchy, L. \& Marion, J.M., 2000. Carte Géologique de Wallonie: Dalhem - Herve 42/3-4. 1/25.000. Namur, Ministère de la Région wallonne, Direction générale des ressources naturelles et de l'environnement, avec une notice explicative de $71 \mathrm{p}$.

Birenheide, R., 1998. Rugose und tabulate Korallen aus der Bohrung Viersen 1001. Fortschritte in der Geologie von Rheinland und Westfalen, 37, 161-213.

Bless, M.J.M., Bouckaert, J., Bouzet, P., Conil, R., Cornet, P., FaironDemaret, M., Groessens, E., Longerstay, P.J., Meesen, J.P.M.T., Paproth, E., Pirlet, H., Streel, M., Van Amerom, H.W.J. \& Wolf, M., 1976. Dinantian Rocks in the subsurface North of the Brabant and Ardenno-Rhenish massifs in Belgium, the Netherlands and the Federal Republic of Germany. Mededelingen Rijks Geologische Dienst, Nieuwe Serie, 27/3, 81-195.

Boulvain, F., Bultynck, P., Coen, M., Coen-Aubert, M., Lacroix, D., Laloux, M., Casier, J.G., Dejonghe, L., Dumoulin, V., Ghysel, P., Godefroid, J., Helsen, S., Mouravieff, N.A., Sartenaer, P., Tourneur, F. \& Vanguestaine, M., 1999. Les formations du Frasnien de la Belgique. Memoirs of the Geological Survey of Belgium, 44, 1-125.

Bultynck, P., 1987. Pelagic and neritic conodont successions from the Givetian of pre-Sahara Morocco and the Ardennes. Bulletin de l'Institut royal des Sciences naturelles de Belgique, Sciences de la Terre, 57, 149-181.

Bultynck, P., Coen-Aubert, M., Dejonghe, L., Godefroid, J., Hance, L., Lacroix, D., Preat, A., Stainier, P., Steemans, P., Streel, M. \& Tourneur, F., 1991. Les formations du Dévonien moyen de la Belgique. Mémoires pour servir à l'explication des Cartes Géologiques et Minières de la Belgique, 30, 1-105.
Bultynck, P. \& Dejonghe, L., 2002. Devonian lithostratigraphic units (Belgium). Geologica Belgica, 4, 39-69.

Coen, M., 1974. Le Frasnien de la bordure orientale du Bassin de Dinant. Annales de la Société Géologique de Belgique, 97, 67103.

Coen-Aubert, M., 1990. Deuxième note sur les Rugueux coloniaux de l'Eifelien supérieur et de la base du Givetien à Wellin (bord sud du Bassin de Dinant, Belgique). Bulletin de l'Institut royal des Sciences naturelles de Belgique, Sciences de la Terre, 60, 5-28.

Coen-Aubert, M., 2003. Description of a few rugose corals from the Givetian Terres d'Haurs Formation in Belgium. Bulletin de l'Institut royal des Sciences naturelles de Belgique, Sciences de la Terre, 73, 11-27.

Coen-Aubert, M., 2008. Fasciculate Disphyllids (Rugosa) from the Early Givetian Trois-Fontaines Formation in Belgium. Bulletin de l'Institut royal des Sciences naturelles de Belgique, Sciences de la Terre, $78,31-50$

Coen-Aubert, M., 2012. New species of Frechastraea Scrutton, 1968 at the base of the Late Frasnian in Belgium. Geologica Belgica, $15,265-272$.

Coen-Aubert, M., 2014. Revision of the Frasnian marine deposits from the Booischot borehole (Campine Basin, Belgium). Geologica Belgica, 17, 333-337.

Coen-Aubert, M., 2015. Revision of the genus Frechastraea Scrutton, 1968 (Rugosa) in the Upper Frasnian of Belgium. Geologica Belgica, 18, 109-125.

Coen-Aubert, M., 2016. Potyphyllum, a new phillipsastreid genus of rugose corals in the Upper Frasnian of Belgium with precisions about the age of the Petit-Mont Member. Geologica Belgica, 19/1-2, 165-175.

Coen-Aubert, M. \& Lacroix, D., 1985. Le Frasnien dans la partie orientale du bord nord du Synclinorium de Namur. Bulletin de la Société belge de Géologie, 94, 117-128.

Cornet, P., 1976. Heibaart 1 et 1 bis. Etude sédimentologique des carottes. Unpublished report from Labofina S.A., Exploration, Centre de Recherche, $14 \mathrm{p}$ with two volumes of photos and comments, stored in the Archives of the Geological Survey of Belgium at Brussels.

Dejonghe, L., 1983. Indice de minéralisation sulfurée $(\mathrm{Fe}, \mathrm{Zn}, \mathrm{Pb}$, $\mathrm{Cu}, \mathrm{Ni}, \mathrm{Co}$ ) liée aux strates du Frasnien (limite F2/F3) dans le sondage d'Heibaart (Loenhout, Province d'Anvers). Bulletin de la Société belge de Géologie, 92, 165-175.

Delcambre, B. \& Pingot, J.L., 2000. Carte Géologique de Wallonie: Fontaine-l'Evêque - Charleroi 46/7-8. 1/25.000. Namur, Ministère de la Région wallonne, Direction générale des ressources naturelles et de l'environnement, avec une notice explicative de $114 \mathrm{p}$.

Delcambre, B. \& Pingot, J.L., 2014. Carte Géologique de Wallonie: Tamines - Fosses-la-Ville 46/5-6. 1/25.000. Namur, Service Public de Wallonie, Direction générale de l'Agriculture, des Ressources naturelles et de l'Environnement, avec une notice explicative de $106 \mathrm{p}$.

Delmer, A., 2004. Tectonique du front varisque en Hainaut et dans le Namurois. Memoirs of the Geological Survey of Belgium, 50, $1-61$.

Denayer, J., Poty, E., Marion, J.M. \& Mottequin, B., 2012. Lower and Middle Famennian (Upper Devonian) rugose corals from southern Belgium and northern France. Geologica Belgica, 15, 273-283.

Denayer, J., Prestianni, C., Gueriau, P., Olive, S. \& Clément, G., 2016. Stratigraphy and depositional environments of the Late Famennian (Late Devonian) of southern Belgium and characterization of the Strud locality. Geological Magazine, 153, 112-127.

Duchesne, J.C., Goemaere, E., Grigolato, J.C., Vanderschueren, H. \& Charlier, B, 2005. Altered rhyolithic rocks in the Visé boreholes: a geochemical approach. Geologica Belgica, 8/3, 71-83.

Dusar, M., Lagrou, D. \& Debacker, T., 2015. Boven-Paleozoïcum tot Mesozoïcum. In Borremans, M. (ed.), Geologie van Vlaanderen. Academia Press, Gent, 58-66.Gouwy, S. \& Bultynck, P., 2000. Graphic correlation of Frasnian sections (Upper Devonian) in the Ardennes, Belgium. Bulletin de l'Institut royal des Sciences naturelles de Belgique, Sciences de la Terre, 70, 25-52.

Gouwy, S. \& Bultynck, P., 2003. Conodont based graphic correlation of the Middle Devonian formations of the Ardenne (Belgium): implications for stratigraphy and construction of a regional composite. Revista Espanola de Micropaleontologia, 35, 315-344. 
Graulich, J.M., Coen-Aubert, M. \& Conil, R., 1975. Le sondage de Hermalle-sous-Argenteau. Service Géologique de Belgique, Professional Paper, 1975/4, 1-12.

Kimpe, W.F.M., Bless, M.J.M., Bouckaert, J., Conil, R., Groessens, E., Meesen, J.P.M.T., Poty, E., Streel, M.,Thorez, J. \& Vanguestaine, M., 1978. Paleozoic deposits East of the Brabant Massif in Belgium and the Netherlands. Mededelingen Rijks Geologische Dienst, 30/2, 37-103.

Klapper, G., Feist, R., Becker, R.T. \& House, M.R., 1993. Definition of the Frasnian/Famennian Stage boundary. Episodes, 16/4, 433-441.

Laenen, B., 2003. Lithostratigrafie van het pre-Tertiair in Vlaanderen, Deel II: Dinantiaan \& Devoon. Studie uitgevoerd in opdracht van de Vlaamse overheid (ANRE). VITO-rapport 2003/ETE/R/095, 86 p

Laenen, B., Dreesen, R. \& Roelandts, I., 2002. Sequence-stratigraphic significance and comparative REE-fractionation patterns of Rupelian glaucony concentrates and Famennian oolitic ironstones (Belgium). Aardkundige Mededelingen, 12, 51-54

Lagrou, D., 2012. Compilatie van de lithostratigrafische eenheden van het Paleozoïcum in Vlaanderen: Perm tot Devoon. Studie uitgevoerd in opdracht van de Vlaamse overheid (ALBON) VITO-rapport 2012/SCT/R/271, $25 \mathrm{p}+$ bijlagen.

Lagrou, D. \& Laenen, B., 2015. Introduction of the Booischot Formation, a new formal lithostratigraphic unit for the Devonian in the Campine Basin (N. Belgium). National Commission for Stratigraphy Belgium, http://ncs.naturalsciences.be/devonian/ booischot-formation, accessed 12/21/2016.

Laloux, M., Dejonghe, L., Ghysel, P. \& Hance, L, 1996. Carte géologique de Wallonie : Fléron-Verviers 42/7-8. 1/25.000. Namur, Ministère de la Région wallonne, Direction générale des ressources naturelles et de l'environnement, avec une notice explicative de $150 \mathrm{p}$.

Langenaeker, V., 2000. The Campine Basin. Stratigraphy, structural geology, coalification and hydrocarbon potential for the Devonian to Jurassic. Aardkundige Mededelingen, 10, 1-142.

Legrand, R., 1964. Coupe résumée du forage de Booischot (Province d'Anvers). Bulletin de la Société belge de Géologie, de Paléontologie et d'Hydrologie, 72, 407-409.

Muchez, P. \& Langenaeker, V., 1993. Middle Devonian to Dinantian sedimentation in the Campine Basin (northern Belgium): it relation to Variscan tectonism. Special Publication of the International Association of Sedimentologists, 20, 171-181.

Neumann-Mahlkau, P. \& Ribbert, K.H., 1998. Die Konglomerate der Givet-Stufe östlich des Brabanter Massivs. Fortschritte in der Geologie von Rheinland und Westfalen, 37, 393-421.

Poty, E., 1982. Paléokarsts et brèches d'effondrement dans le Frasnien moyen des environs de Visé. Leur influence dans la paléogéographie dinantienne. Annales de la Société Géologique de Belgique, 105, 315-337.

Poty, E., 1991.Tectonique de blocs dans le prolongement oriental du Massif du Brabant. Annales de la Société Géologique de Belgique, $114,265-275$

Poty \& Delculée, S., 2011. Interaction between eustacy and blockfaulting in the Carboniferous of the Visé-Maastrict area (Belgium, The Netherlands). Zeitschrift der Deutschen Gesellschaft für Geowissenschaften, 162/2, 117-126.

Ribbert, K.H., 1982. Die Konglomerate des Schwarzbachtales, ein sedimentologisches Modell. Senckenbergiana lethaea, 63, 345 358.

Ribbert, K.H., 1998. Tabelle R 005 dm 97, Velberter Sattel; Mittel Devon. In Weddige, K. (ed.), Devon-Korrelationstabelle Senckenbergiana lethaea, 77, 309.

Sorauf, J.E., 1967. Massive Devonian Rugosa of Belgium. The University of Kansas Paleontological Contributions, 16, 1-41.

Streel, M., 1965. Etude palynologique du Dévonien du sondage de Booischot. Bulletin de la Société belge de Géologie, de Paléontologie et d'Hydrologie, 73, 172-185.

Streel, M. \& Loboziak, S., 1987. Nouvelle datation par miospores du Givetien-Frasnien des sédiments non marins du sondage de Booischot (Bassin de Campine, Belgique). Bulletin de la Société belge de Géologie, 96, 99-106.

Streel, M. \& Paproth, E., 1982. Mitteldevonische Sporen aus der Bohrung Schwarzbachtal 1. Senckenbergiana lethaea, 63, 175-181.

Thorez, J., Dreesen, R. \& Streel, M., 2006. Famennian. Geologica Belgica, 9, 27-45.

Vanguestaine, M., Declairfayt, T., Rouhart, A. \& Smeesters, A., 1983. Zonation par Acritarches du Frasnien supérieur- Famennien inférieur dans les Bassins de Dinant, Namur, Herve et Campine (Dévonien supérieur de Belgique). Annales de la Société Géologique de Belgique, 106, 121-171
Ziegler, W. \& Sandberg, C.A., 1990. The Late Devonian standard conodont zonation. Courier Forschungsinstitut Senckenberg, $121,1-115$.
Manuscript received 28.04.2016, accepted in revised form 29.11.2016, available on line 10.01.2017. 

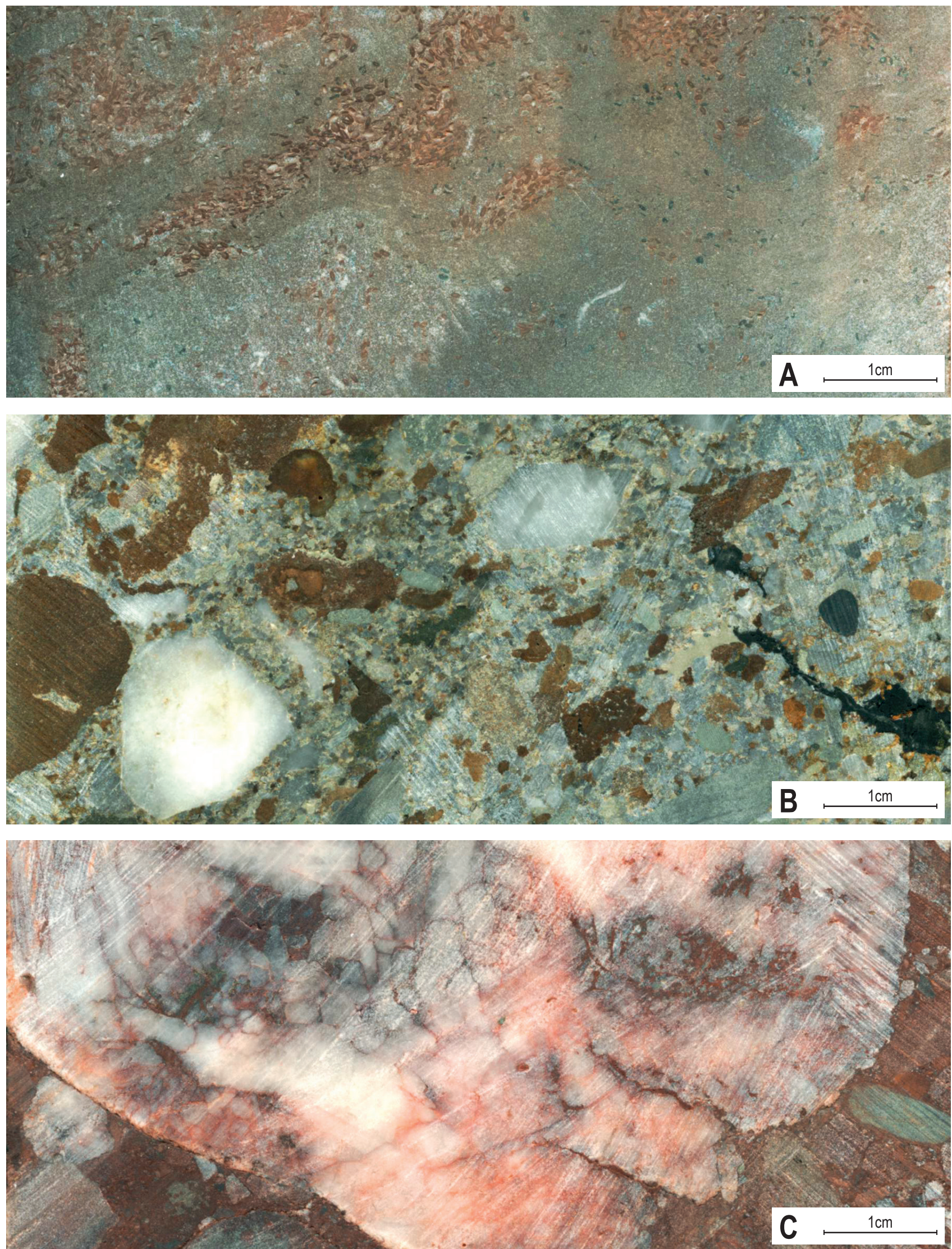

Plate 1. Pictures of the cores of the Booischot borehole (KB132, 59E0146) (Dusar et al., 2015). A: Nodular purple, slightly silty limestone with small bioclasts and oolits. The nodular (cloudy) structure is the result of intense bioturbation, but also of the changing grainsize in the recrystallization of the carbonate matrix; its dark part is fine-grained and micritic whereas its paler part is coarse-grained and sparitic. Iron oolites are coloured in red by hematite, 1 to $2 \mathrm{~cm}$ in size and flattened (lens shaped) with a hollow core. They occur in a concentrated manner characterized by $\mathrm{cm}$ thick bands with sparite matrix, but they are also scattered due to the bioturbation, which indicates that they constitute an original component of the sediment. Aisemont Formation at $891 \mathrm{~m}$. B: Polymictic conglomerate of well-rounded hard grey sandstone, quartz and sometimes poorly rounded, softer red sandstone, with pebbles of 1 or $2 \mathrm{~cm}$ up to $8 \mathrm{~cm}$ in diameter, embedded in a matrix of very well-rounded gravels, almost without fine grained binder. The sandstone exhibits a variable texture, from very fine to very coarse. The origin is clearly detrital with river transport. Booischot Formation at $921 \mathrm{~m}$. C: Polymictic conglomerate of closely packed, well-rounded pebbles and boulders of grey to red sandstone, siltstone and quartz, embedded in a red matrix consisting of well-rounded gravels with clay binder. The hematite colour of the matrix has also penetrated into the pebbles and indicates a fluvial transport in hot and dry environment. Booischot Formation at $1171 \mathrm{~m}$. 

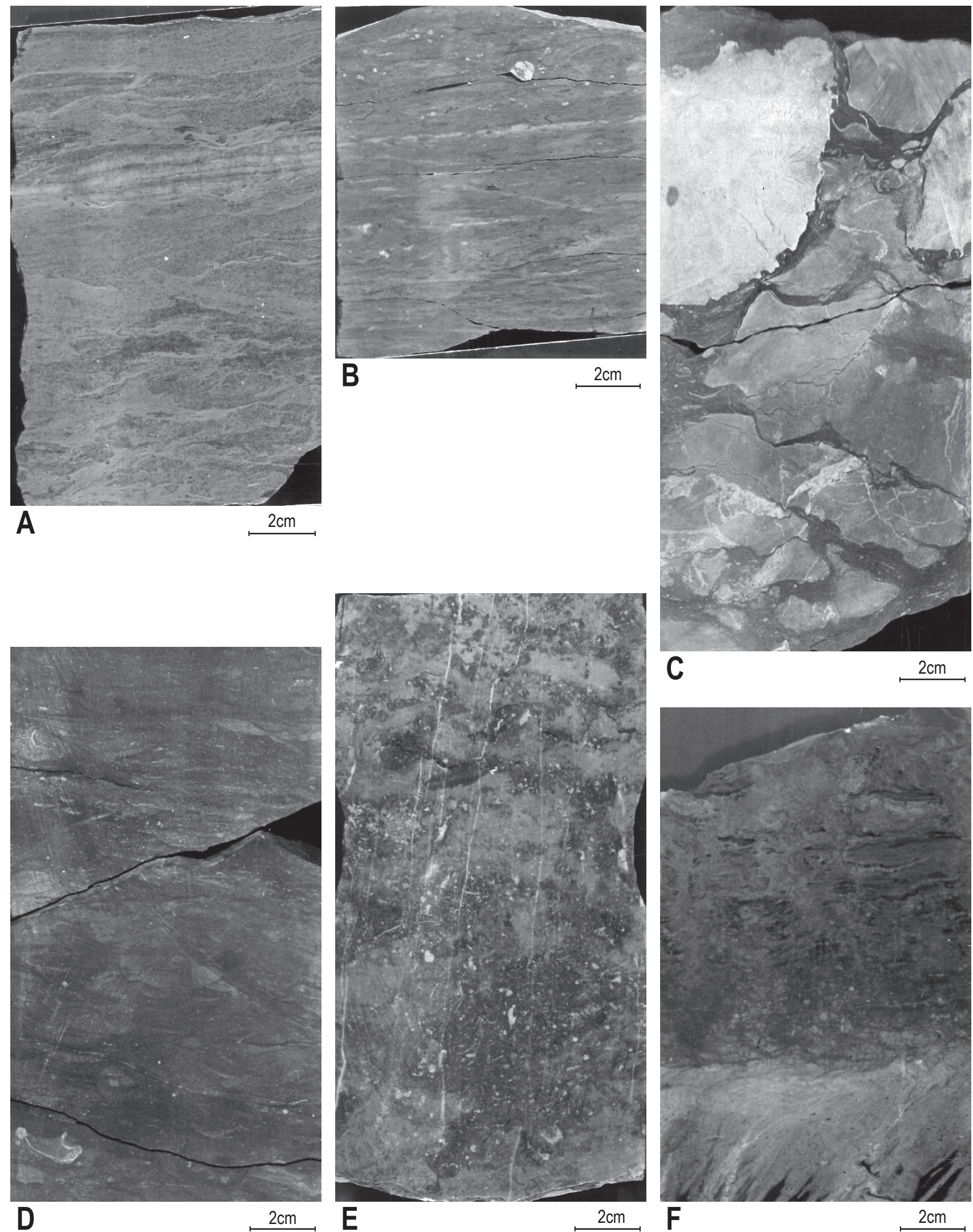

Plate 2. Pictures of the cores of the Heibaart borehole (KB129, 007E0178). A: Green to reddish, fine-grained, argillaceous sandstone, bioturbated and mottled in the lower part of the core. Evieux Formation from $1489.55 \mathrm{~m}$ to $1489.70 \mathrm{~m}$. B: Silto-micaceous and slightly bioclastic mudstone with a fragment of crinoid close to the top of the core. Falisolle Formation from $1587.96 \mathrm{~m}$ to $1588.07 \mathrm{~m}$. C: Nodular, slightly bioclastic limestone with two fragments of massive rugose corals in the upper part; probably Potyphyllum ananas for the left colony. Aisemont Formation from $1596.35 \mathrm{~m}$ to $1596.55 \mathrm{~m}$. D: Slightly bioclastic, calcareous shale with a few fragments of brachiopods. Aisemont Formation from $1603.00 \mathrm{~m}$ to $1603.26 \mathrm{~m}$. E: Bioclastic dolomite, with a fragment of a recrystallized ramose tabulate coral in the upper part of the core, on the left. Aisemont Formation from $1623.25 \mathrm{~m}$ to $1623.44 \mathrm{~m}$. F: Angular unconformity between strongly inclined Silurian slates and more or less horizontal dolomitic marlstones of the Huccorgne Formation. Occurrence of intraclasts at the base of the Frasnian lithostratigraphic unit intersected by some vertical structures suggesting traces of roots. Contact of the Huccorgne Formation with the Brabant Massif from $1627.66 \mathrm{~m}$ to $1627.82 \mathrm{~m}$. 